\title{
THE CHOLESTEROL TOLERANCE TEST IN NORMAL INDIVIDUALS
}

\author{
BY \\ NAZEK I. FAHMY AND PAUL GHALIOUNGUI \\ From the Department of Clinical Medicine and the Abbassiah Faculty of \\ Medicine, Cairo
}

(RECEIVED FOR PUBLICATION OCTOBER 19, 1951)

There are different opinions about the effect of a cholesterol-rich meal on the blood cholesterol.

Gardner and Gainsborough (1928), in their work on the cholesterol content of normal human plasma, came to the following conclusions on the so-called alimentary hypercholesterolaemia. (1) The level of the cholesterol content of human plasma in the fasting state can be raised or lowered by prolonged feeding with diets of high or low sterol content. Such changes are most marked as regards the cholesterol esters, while the free cholesterol remains practically constant. (2) Alimentary hypercholesterolaemia does not occur as the result of a single meal, a fact in accordance with Mjassnikow's (1926) views. Moreover, there is no connexion between the amount of sterol ingested and the cholesterol level of the plasma during digestion. They also concluded that the plasma cholesterol under normal and pathological conditions must be estimated in the fasting state. This is also the opinion of McEachen and Gilmour (1932), of McClure and Huntsinger (1928), of Gardner (1932), and of Bruger and Somach (1932), who observed physiological variations in the hourly blood cholesterol levels that led them to the conclusion that blood samples must be taken before breakfast.

Nepveux and Uhry mention (1936) that Goodman, Grigaut, Bacmeister, Laudat, McClure, and Huntsinger observed an elevation of the blood cholesterol parallel to the curve of lipaemia after the ingestion of any type of food, but especially after the absorption of cholesterol and egg yolk. They also mention (1936) that Leites, Martini, Bruger, and Oeter differentiated between digestive hypercholesterolaemia and alimentary hypercholesterolaemia. The former occurs without any dietary intervention, since the mere exciting of digestive secretions by the injection of dilute hydrochloric acid in the duodenum can provoke it. It is observed from the beginning of the evacuation of the stomach, whereas hypercholesterolaemia due to intestinal absorpion comes on later.

Since cholesterol appears more and more related to vascular changes, it would be of real value to estimate the individual's cholesterol tolerance early in life. Should this tolerance be poor, one could attempt by a cholesterol-poor diet to maintain a normal blood cholesterol level (Burns, 1948).

Our attention was attracted to the effect of meals on the blood cholesterol by 15 cases (Table I) in which the blood taken before lunch but five hours after break- 
fast showed unusually high values (ranging from $243.9 \mathrm{mg}$. to $200 \mathrm{mg}$., average 219.2 mg. \%), as compared with the normal fasting blood cholesterol in Egyptians which, in our experience, is $115 \mathrm{mg}$. to $199 \mathrm{mg}$. \%.

TABLE I

EfFect of Meals on Blood Cholesterol

\begin{tabular}{|c|c|c|}
\hline No. & Sex & Total (mg./100 ml.) \\
\hline $\begin{array}{r}1 \\
2 \\
3 \\
4 \\
5 \\
6 \\
7 \\
-8 \\
9 \\
10 \\
11 \\
12 \\
13 \\
14 \\
15\end{array}$ & $\begin{array}{c}\text { Male } \\
\text {," } \\
,, \\
, \\
,, \\
,, \\
\text { Female } \\
\text {," } \\
,, \\
,,\end{array}$ & $\begin{array}{l}212 \cdot 7 \\
217 \cdot 3 \\
204 \cdot 4 \\
230 \cdot 0 \\
212 \cdot 7 \\
227 \cdot 3 \\
208 \cdot 3 \\
239 \cdot 2 \\
200 \cdot 0 \\
204 \cdot 1 \\
210 \cdot 7 \\
243 \cdot 9 \\
220 \cdot 7 \\
217 \cdot 4 \\
240 \cdot 3\end{array}$ \\
\hline
\end{tabular}

A decision was first made to estimate the cholesterol value before breakfast and before the midday meal, i.e., five hours later, in the same individuals. As can be seen from Table II, it was higher in the later specimen, and it was therefore decided to estimate the effect of a standard breakfast.

TABLE II

Results fasting and Five Hours after Breakfast in the Same Individuals

\begin{tabular}{c|c|l|c}
\hline No. & Sex & \multicolumn{1}{|c|}{ Condition } & $\begin{array}{c}\text { Total } \\
\text { (mg./100 ml.) }\end{array}$ \\
\cline { 2 - 4 } & Male & Fasting & $181 \cdot 8$ \\
2 &, & 5 hrs. after breakfast & $257 \cdot 7$ \\
3 &, & Fasting & $173 \cdot 0$ \\
& 5 hrs. after breakfast & $212 \cdot 7$ \\
& & Fasting & $192 \cdot 3$ \\
& & 5 hrs. after breakfast & $212 \cdot 7$ \\
\hline
\end{tabular}

\section{Experimental Procedure}

Blood was taken in the morning before the ingestion of any food; a meal was then given consisting of three eggs, $50 \mathrm{~g}$. butter, $50 \mathrm{~g}$. cheese, $200 \mathrm{~g}$. milk, $190 \mathrm{~g}$. bread, and $80 \mathrm{~g}$. cooked beans. The average amount of cholesterol in one Egyptian egg yolk was found by chemical analysis to be $351.6 \mathrm{mg}$., and the average weight of one yolk is $16 \mathrm{~g}$. Three hours and five hours after this meal blood was again taken. Exactly five hours after breakfast five subjects "were given a lunch consisting of $200 \mathrm{~g}$. rice, $100 \mathrm{~g}$. meat, $200 \mathrm{~g}$. potatoes, two oranges, and $188 \mathrm{~g}$. bread. Three hours after taking this meal (eight hours after breakfast) blood specimens were again withdrawn. In one case only another specimen was taken four and a half hours after lunch. 
TABLE III

Results Fasting and at Specified Intervals After Meals

\begin{tabular}{|c|c|c|c|c|c|c|c|}
\hline \multirow{2}{*}{ No. } & \multirow{2}{*}{ Age } & \multirow{2}{*}{ Sex } & \multirow{2}{*}{ Fasting } & \multicolumn{2}{|c|}{ Hours after Breakfast } & \multicolumn{2}{|c|}{ Hours after Lunch } \\
\hline & & & & 3 Hours & 5 Hours & 3 Hours & $4 \frac{1}{2}$ Hours \\
\hline $\begin{array}{l}1 \\
2 \\
3 \\
4 \\
5\end{array}$ & $\begin{array}{l}24 \\
30 \\
30 \\
32 \\
39\end{array}$ & $\begin{array}{l}\text { F. } \\
\text { M. } \\
\text { M. } \\
\text { M. } \\
\text { M. }\end{array}$ & $\begin{array}{l}161.3 \\
192.3 \\
181.8 \\
181.8 \\
173.0\end{array}$ & $\begin{array}{l}208 \cdot 3 \\
200 \cdot 0 \\
166 \cdot 6 \\
217 \cdot 4 \\
181 \cdot 8\end{array}$ & $\begin{array}{l}215 \cdot 5 \\
212 \cdot 7 \\
189 \cdot 4 \\
257 \cdot 7 \\
212.7\end{array}$ & $\begin{array}{l}169 \cdot 4 \\
167 \cdot 2 \\
175 \cdot 0 \\
227 \cdot 3 \\
188 \cdot 6\end{array}$ & $238 \cdot 1$ \\
\hline
\end{tabular}

It was then decided to follow the effect of the standard breakfast alone for seven hours without the complicating factor of the lunch.

Tables IV, V, VI, and VII illustrate these results in 10 normal subjects for total, free, and esterified cholesterol respectively.

TABLE IV

Effect of Standard Breakfast in Ten Normal Subjects for Total Cholesterol

\begin{tabular}{|c|c|c|c|c|c|c|}
\hline \multirow{2}{*}{ No. } & \multirow{2}{*}{ Sex } & \multirow{2}{*}{ Age } & \multirow{2}{*}{ Fasting } & \multicolumn{3}{|c|}{ Hours after Breakfast } \\
\hline & & & & 3 & 5 & 7 \\
\hline $\begin{array}{r}1 \\
2 \\
3 \\
4 \\
5 \\
6 \\
7 \\
8 \\
9 \\
10\end{array}$ & $\begin{array}{l}\text { M. } \\
\text { M. } \\
\text { M. } \\
\text { M. } \\
\text { M. } \\
\text { M. } \\
\text { M. } \\
\text { M. } \\
\text { M. } \\
\text { M. }\end{array}$ & $\begin{array}{l}28 \\
75 \\
22 \\
32 \\
20 \\
33 \\
38 \\
30 \\
30 \\
14\end{array}$ & $\begin{array}{l}195 \cdot 3 \\
190 \cdot 8 \\
161 \cdot 3 \\
185 \cdot 1 \\
147 \cdot 1 \\
147 \cdot 7 \\
175 \cdot 5 \\
133 \cdot 3 \\
133 \cdot 3 \\
133 \cdot 3\end{array}$ & $\begin{array}{l}208 \cdot 3 \\
173 \cdot 0 \\
157 \cdot 2 \\
172 \cdot 4 \\
167 \cdot 7 \\
142 \cdot 8 \\
196 \cdot 1 \\
159 \cdot 0 \\
144 \cdot 9 \\
133 \cdot 3\end{array}$ & $\begin{array}{l}212 \cdot 7 \\
219 \cdot 2 \\
175 \cdot 5 \\
192 \cdot 3 \\
190 \cdot 8 \\
188 \cdot 6 \\
208 \cdot 3 \\
169 \cdot 4 \\
161 \cdot 3 \\
140 \cdot 8\end{array}$ & $\begin{array}{l}190 \cdot 1 \\
186 \cdot 5 \\
172 \cdot 4 \\
181 \cdot 8 \\
147 \cdot 0 \\
163 \cdot 9 \\
156 \cdot 2 \\
121 \cdot 9 \\
147 \cdot 1 \\
125 \cdot 0\end{array}$ \\
\hline Average & & & $160 \cdot 3$ & $165 \cdot 5$ & 185.9 & $159 \cdot 2$ \\
\hline
\end{tabular}

TABLE V

Effect of Standard Breakfast on 10 Normal Subjects for Free Cholesterol

\begin{tabular}{|c|c|c|c|c|c|c|}
\hline \multirow{2}{*}{ No. } & \multirow{2}{*}{ Sex } & \multirow{2}{*}{ Age } & \multirow{2}{*}{ Fasting } & \multicolumn{3}{|c|}{ Hours after Breakfast } \\
\hline & & & & 3 & 5 & 7 \\
\hline $\begin{array}{r}1 \\
2 \\
3 \\
4 \\
5 \\
6 \\
7 \\
8 \\
9 \\
10\end{array}$ & $\begin{array}{l}\text { M. } \\
\text { M. } \\
\text { M. } \\
\text { M. } \\
\text { M. } \\
\text { M. } \\
\text { M. } \\
\text { M. } \\
\text { M. } \\
\text { M. }\end{array}$ & $\begin{array}{l}28 \\
75 \\
22 \\
32 \\
20 \\
33 \\
38 \\
30 \\
30 \\
14\end{array}$ & $\begin{array}{l}130 \cdot 8 \\
132 \cdot 0 \\
135 \cdot 4 \\
131 \cdot 1 \\
116 \cdot 7 \\
116 \cdot 0 \\
125 \cdot 5 \\
102 \cdot 1 \\
100 \cdot 0 \\
100 \cdot 0\end{array}$ & $\begin{array}{l}139 \cdot 4 \\
121.2 \\
123.9 \\
121 \cdot 2 \\
129 \cdot 3 \\
102 \cdot 8 \\
151 \cdot 7 \\
125 \cdot 2 \\
122.6 \\
113.9\end{array}$ & $\begin{array}{l}150 \cdot 2 \\
175 \cdot 4 \\
143 \cdot 8 \\
127 \cdot 0 \\
155 \cdot 1 \\
156 \cdot 3 \\
169 \cdot 8 \\
150 \cdot 2 \\
139 \cdot 6 \\
108.5\end{array}$ & $\begin{array}{r}143 \cdot 6 \\
151.8 \\
126.9 \\
114 \cdot 3 \\
94.5 \\
117 \cdot 0 \\
108 \cdot 6 \\
101 \cdot 1 \\
126.9 \\
111.2\end{array}$ \\
\hline Average & & & 118.6 & $125 \cdot 1$ & $147 \cdot 9$ & $119 \cdot 6$ \\
\hline
\end{tabular}


TABLE VI

Effect of Standard Breakfast on 10 Normal SubJects for Esterified Cholesterol

\begin{tabular}{|c|c|c|c|c|c|c|}
\hline \multirow{2}{*}{ No. } & \multirow{2}{*}{ Sex } & \multirow{2}{*}{ Age } & \multirow{2}{*}{ Fasting } & \multicolumn{3}{|c|}{ Hours after Breakfast } \\
\hline & & & & 3 & 5 & 7 \\
\hline $\begin{array}{r}1 \\
2 \\
3 \\
4 \\
5 \\
6 \\
7 \\
8 \\
9 \\
10\end{array}$ & $\begin{array}{l}\mathrm{M} . \\
\mathrm{M} . \\
\mathrm{M} \\
\mathrm{M} . \\
\mathrm{M} . \\
\mathrm{M} . \\
\mathrm{M} . \\
\mathrm{M} . \\
\mathrm{M} . \\
\mathrm{M} .\end{array}$ & $\begin{array}{l}28 \\
75 \\
22 \\
32 \\
20 \\
33 \\
38 \\
30 \\
30 \\
14\end{array}$ & $\begin{array}{l}64 \cdot 5 \\
58 \cdot 8 \\
25.9 \\
54 \cdot 0 \\
30 \cdot 4 \\
31 \cdot 7 \\
50 \cdot 0 \\
31 \cdot 2 \\
33 \cdot 3 \\
33 \cdot 3\end{array}$ & $\begin{array}{l}68.9 \\
51.8 \\
33 \cdot 3 \\
51.2 \\
38 \cdot 4 \\
40.0 \\
44.4 \\
33.8 \\
22.3 \\
19 \cdot 4\end{array}$ & $\begin{array}{l}62 \cdot 5 \\
43 \cdot 8 \\
31 \cdot 7 \\
65 \cdot 3 \\
35 \cdot 7 \\
32 \cdot 3 \\
38 \cdot 5 \\
19 \cdot 2 \\
21 \cdot 7 \\
32 \cdot 3\end{array}$ & $\begin{array}{l}46 \cdot 5 \\
34 \cdot 7 \\
45 \cdot 5 \\
67 \cdot 5 \\
42 \cdot 5 \\
46 \cdot 5 \\
47 \cdot 6 \\
20 \cdot 8 \\
20 \cdot 2 \\
13 \cdot 8\end{array}$ \\
\hline Average & & & $41 \cdot 3$ & $40 \cdot 4$ & $38 \cdot 3$ & $38 \cdot 6$ \\
\hline
\end{tabular}

Table VII illustrates the cholesterol ester as percentages of the total in the fasting state three, five, and seven hours after the ingestion of the standard breakfast in the same 10 normal individuals.

TABLE VII

Cholesterol Ester as Percentages of Total Cholesterol in 10 Normal Subjects at SPECIFIEd INTERVAls after Standard Breakfast

\begin{tabular}{|c|c|c|c|c|c|c|}
\hline \multirow{2}{*}{ No. } & \multirow{2}{*}{ Sex } & \multirow{2}{*}{ Age } & \multirow{2}{*}{ Fasting } & \multicolumn{3}{|c|}{ Hours after Breakfast } \\
\hline & & & & 3 & 5 & 7 \\
\hline $\begin{array}{r}1 \\
2 \\
3 \\
4 \\
5 \\
6 \\
7 \\
8 \\
9 \\
10\end{array}$ & $\begin{array}{l}\text { M. } \\
\text { M. } \\
\text { M. } \\
\text { M. } \\
\text { M. } \\
\text { M. } \\
\text { M. } \\
\text { M. } \\
\text { M. } \\
\text { M. }\end{array}$ & $\begin{array}{l}28 \\
75 \\
22 \\
32 \\
20 \\
33 \\
38 \\
30 \\
30 \\
14\end{array}$ & $\begin{array}{l}33 \cdot 0 \\
30 \cdot 8 \\
16 \cdot 1 \\
29 \cdot 1 \\
20 \cdot 6 \\
21 \cdot 4 \\
28 \cdot 4 \\
30 \cdot 5 \\
24 \cdot 9 \\
24 \cdot 9\end{array}$ & $\begin{array}{l}33 \cdot 1 \\
29.9 \\
11 \cdot 2 \\
29.7 \\
22.9 \\
28 \cdot 0 \\
18 \cdot 5 \\
21 \cdot 2 \\
15.4 \\
14.5\end{array}$ & $\begin{array}{l}29.4 \\
19 \cdot 8 \\
18 \cdot 6 \\
33.9 \\
17 \cdot 8 \\
17 \cdot 1 \\
22 \cdot 6 \\
11 \cdot 3 \\
13 \cdot 4 \\
22.9\end{array}$ & $\begin{array}{l}24 \cdot 5 \\
18 \cdot 6 \\
26 \cdot 3 \\
37 \cdot 1 \\
28 \cdot 9 \\
28 \cdot 6 \\
30 \cdot 5 \\
17 \cdot 1 \\
13 \cdot 6 \\
11 \cdot 0\end{array}$ \\
\hline Average & & & $25 \cdot 9$ & $23 \cdot 4$ & $20 \cdot 6$ & $23 \cdot 6$ \\
\hline
\end{tabular}

\section{Results}

The fasting total blood cholesterol in the 10 normal individuals investigated varied from 133.3 to $195.3 \mathrm{mg}$. $/ 100 \mathrm{ml}$., the average being $160.3 \mathrm{mg}$./100 ml. After a cholesterol-rich breakfast there was observed in all cases a definite rise in the cholesterol curve which reached its maximum after five hours and returned almost to fasting level after seven hours. The increase was mainly due to an increase in free cholesterol. The ester level remained almost constant throughout the experiment.

Estimation of blood taken three hours after the standard breakfast showed in most cases a rise in the total cholesterol, but in a few cases values lower than the 
fasting ones were observed. It is possible that the immediate result of a meal is an increased excretion and consequent lowering of the blood cholesterol, which is later corrected by absorption from the intestine. If this absorption is delayed the resulting lowering of the blood cholesterol is prolonged. This explanation is supported by the finding that the total blood cholesterol after five hours reached a maximum level in all cases.

The total blood cholesterol seven hours after ingestion of the standard breakfast was equal to, above, or below the fasting level. This can be explained (Bloor, 1943) by the fact that cholesterol is readily synthesized as required, and that any excess is normally excreted. Thus, after five hours it reaches a maximum in the blood, and any excess is excreted, either in the bile or, as coprosterol, by the intestine.

In the case of the five normal subjects whose blood cholesterol was estimated also three hours after taking the standard lunch, the total blood cholesterol was found to be lower than after the five hours level. It is probable that sufficient time had not elapsed for the postprandial increase to occur.

The total blood cholesterol showed another maximum level four and a half hours after lunch similar to that found five hours after breakfast.

\section{Summary}

Contrary to the statements of various workers that the changes in the blood cholesterol after a single meal are variable, the present workers have found a definite cholesterol tolerance curve in normal individuals which can be obtained after the ingestion of a meal rich in cholesterol. This curve shows the following characteristics: (1) a maximum level for total blood cholesterol five hours after ingestion; (2) a return almost to fasting level seven hours after ingestion; (3) the increase is mainly due to an increase in the free cholesterol, since the level of the esters remained nearly the same throughout the experiment.

\section{REFERENCES}

Bloor, W. R. (1943). Biochemistry of the fatty acids, p. 313. New York.

Bruger, M., and Somach, I. (1932). J. biol. Chem., 97, 23.

Burns, F. J. (1948). R.I. med. J., 31, 103.

Gardner, J. A. (1932). Brit. med. J., 2, 392.

and Gainsborough, H. (1928). Biochem. J., 22, 1048.

McEachern, J. M., and Gilmour, C. R. (1932). Canad. med. Ass. J., 26, 30.

McClure, C. W., and Huntsinger, M. E. (1928). J. biol. Chem., 76, i.

Mjassnikow, A. L. (1926). Z. klin. Med., 103, 767.

Nepveux, F., and Uhry, P. (1936). "Glands endocrines et Nutrition,” 10536, p. 1. Paris. In Encyclopédie médico chirurgicale, ed. Laffont, A., and Durieux. 
and leg. A third son, aged 29, had numerous lesions of face and ears, with a duration possibly of 16 years. Two other sons were not affected: the grandfather probably was affected. It was found that the lesions were much less radiosensitive than might be expected from their histological nature.

B. Lennox.

My Conception of Cellular Nevi. Masson, P. (1951). Cancer, 4, 9.

This outline of the neurogenic hypothesis of the origin of pigmented naevi by its originator is clear and timely. The origin of naevi is said to be twofold, from epidermal melanoblasts which multiply and spread into the dermis, and from the Schwann cells of the cutaneous nerves which multiply and infiltrate the deeper dermis. These two components merge and become indistinguishable from each other. The epidermal melanoblasts are specific cells, distinct from the rest of the epidermal cells; their precise source developmentally is still debatable, possibly from the neural crest, possibly from the epidermis itself. In a pigmented naevus which has become malignant it is very difficult to determine histologically whether both of the two components of the naevus may have been the source of the growth. While there is no doubt that malignant change often involves the epidermal melanoblasts, two specimens lead the author to believe that the "neuroid" elements could have been the source of the growths.

R. A. Willis.

\section{Frequency and Form of Primary Cancer of the Liver. Zeitlhofer, J. (1951). Krebsarzt, 6, 154.}

In this paper is reported a study of the incidence of primary cancer of the liver based upon the post-mortem records of the Pathological Anatomical Institute in Vienna. The work was undertaken to investigate whether the use of "butter yellow" has affected the incidence of this disease. The investigation covered three periods: 1900-12, when no butter yellow was in use; 192C-32, when it was used to some extent; and 1938-50, when it was used to a much greater extent. From an analysis of the figures it appears that there has not been any actual increase in primary liver cancer during the halfcentury, but that the diffuse form of the disease has tended to increase and the nodular form to decrease. When the incidence of cirrhosis of the liver was investigated, there was found to be a significant increase over the same period. [Similar figures for large series of cases are required to exclude the errors which are inevitable when dealing with small numbers in a disease of such rarity.] H. Russell (Excerpta Medica).

Primary Carcinoma of the Liver in Hemochromatosis. Warren, S., and Drake, W. L. (1951). Amer. J. Path., 27, 573.

The incidence of hepatic carcinoma in various reported series of post-mortem examinations in cases of haemochromatosis ranges between $11 \%$ and $43 \%$. In a personal series of 20 cases 6 cases of carcinoma of the liver were found-an incidence of $30 \%$. Combining the authors figures with those of earlier reports, among 127 cases of haemochromatosis there were 24 of hepatic carcinomaan incidence of $18.9 \%$. The average age of the patients in the authors' cases of uncomplicated haemochromatosis was 56.3 years, and of those with carcinoma 65.5 years. Carcinoma occurred in some cases with only mild cirrhosis, and cannot be attributed solely to excessive regenerative hyperplasia resulting from cirrhosis. The frequent development of carcinoma in haemochromatosis " is doubtless linked to the cause or causes" of this disorder, which " provides a setting for carcinogenesis more effective than simple portal cirrhosis."

$$
\text { R. A. Willis. }
$$

Glycogen Storage Disease. I. Familial Cardiac Glycogen Storage Disease: Report of Two Cases and Discussion of Relation to Other Forms of Abnormal Glycogen Deposition. Landing, B. H., and Bangle, R. (1950). Bull. int. Ass. med. Mus., 31, 84. Bibliography.

The clinical features and necropsy and histological findings are described in 2 cases of cardiac glycogenstorage disease occurring in brothers who died aged 43 months and $2 \frac{1}{2}$ months repectively. Necropsy was performed 5 and 8 hours after death respectively and the chief finding was gross cardiac enlargement. The heart weights were $67 \mathrm{~g}$. (normal $27 \mathrm{~g}$.) and $88.5 \mathrm{~g}$. (normal 23 g.). The ductus arteriosus was closed and there was a patent, slit-like foramen ovale in both cases. Histologically, the heart muscle fibres contained large central "vacuoles" surrounded by a fringe of myofibrils. The "vacuoles" failed to take fat stains, but were coloured by Best's carmine and periodic acid-leukofuchsin stains.

On searching the literature the authors found 35 cases of the disease reported, of which 31 are summarized in tabular form. The condition appears to occur in two well-defined age groups, namely, in infancy and during adolescence, and, like many other metabolic disorders, is the more severe and rapidly progressive, the younger the patient. From the literature available the authors conclude that cardiac glycogen-storage disease differs from the hepatic form in that the former may be a sexlinked condition, whereas the latter probably is not. The available evidence is inconclusive as to whether the disease is inherited as a Mendelial dominant or recessive character. No case embodying both cardiac and hepatic glycogen storage has so far been described.

Single and multiple rhabdomyomatosis is probably commoner than cardiac glycogen-storage disease, the histulogy of the two diseases is different, and the former condition tends to be associated with tuberous sclerosis.

"Diffuse cardiac rhabdomyomatosis" in all probability does not exist as a definite disease entity.

\section{R. B. T. Baldwin.}

Correction :-Professor Ghalioungui regrets that he omitted to include the name of Professor M. M. Fikry in the acknowledgments (J. clin. Path., 5, 203). 